$$
\begin{aligned}
& \text { اثر نانو اكسيد آهن بر رشد، فيزيولوزى و كالزايِى فلفل در شيشه } \\
& \text { عليرضا اير انبخش و سيدعليرضا قادرى } \\
& \text { كروه زيست شناسى، واحد علوم و تحقيقات، دانشعاه آزاد اسلامى، تهران، ايران } \\
& \text { مسئول مكاتبات: عليرضا ايرانبخش، iranbakhsh@iau.ac.ir }
\end{aligned}
$$

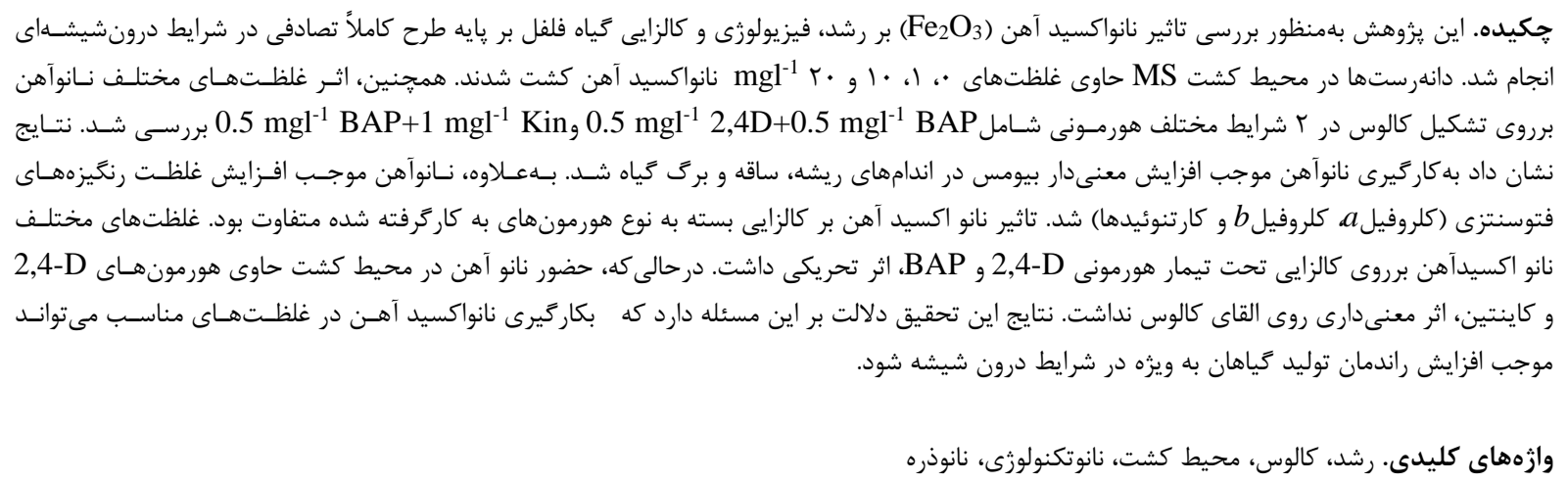

\title{
The effect of nano-iron oxide on growth, physiology, and callogenesis in pepper in vitro
}

\author{
Alireza Iranbakhsh \& Seyed Alireza Ghaderi \\ Department of Biology, Science and Research branch, Islamic Azad University, Tehran, Iran \\ Corresponding author: Alireza Iranbakhsh, iranbakhsh@iau.ac.ir
}

\begin{abstract}
The aim of this research was to study the effect of iron oxide nanoparticles (FeO NPs) on the growth, differentiation, anatomy, and physiology of pepper (Capsicum annuum L.) on the basis of a completely randomized design in vitro condition. Seedlings were cultured in MS medium containing four concentrations of FeO NPs $(0,1,10$, and $\left.20 \mathrm{mgl}^{-1}\right)$. Also, the effect of the different concentrations of $\mathrm{FeO} \mathrm{NPs}$ on callus formation under two various hormone conditions $\left(0.5 \mathrm{mgl}^{-1} 2,4 \mathrm{D}+0.5 \mathrm{mgl}^{-1} \mathrm{BAP}\right.$ or $\left.0.5 \mathrm{mgl}^{-1} \mathrm{BAP}+1 \mathrm{mgl}^{-1} \mathrm{Kin}\right)$ were assessed. The results showed that the application of FeO NPs significantly increased biomass accumulation in both roots and shoots. Moreover, FeO NPs enhanced the concentrations of photosynthesis pigments (chllrophyll $a$, chlorophyll $b$, and carotenoids). The presence of $\mathrm{FeO} \mathrm{NPs}$ in culture medium affected callus formation in a hormone-dependent manner. Different concentration of FeO NPs induced the callus formation under 2, 4-D and BAP treatments. However, it did not significantly increase callus formation under the kinitin and 2,4-D. The findings of this research indicated that the application of FeO NPs at optimized doses may improve plant production, especially in vitro condition.
\end{abstract}

Keywords. callus, culture medium, growth, nanoparticle, nanotechnology

Received 19.06.2018/ Revised 28.07.2019/ Accepted 16.09.2019/ Published 01.07.2020 دريافت: 
سـازى دارد (Barberon et al., 2011). آهــن در بيوسـنتز

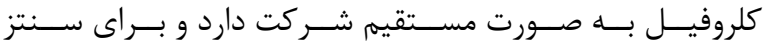

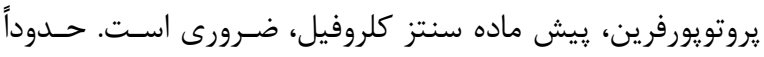

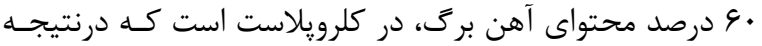

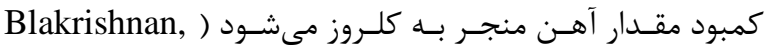

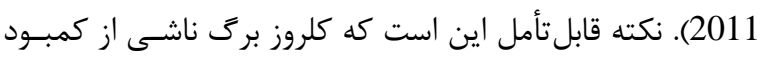
آهن يك نابسامانى تغذيهاى گسترده در گياهان است كه ميتواند

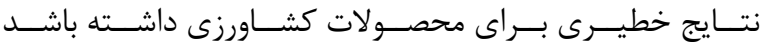
Lombardi et al., 2003) غلظتهاى مختلف نانوذرات اكسيد آهن اثرات مثبت بر زندهمانى و اندازه كالوس دارد (Sharafi et al., 2013). در گياه كل راعى،

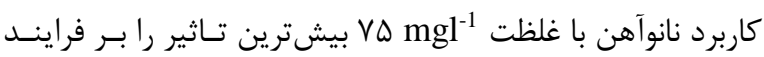

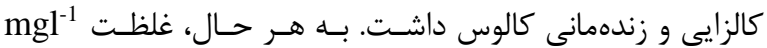

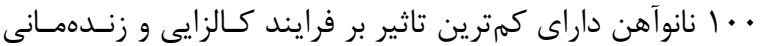
كالوس بود (Sharafi et al., 2013). در كياه اسفناج نيز ميـزان

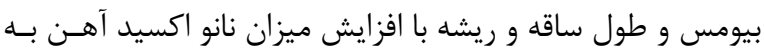

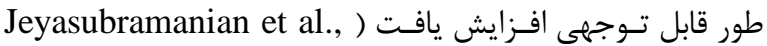

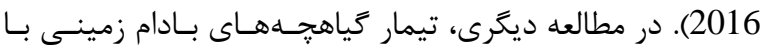

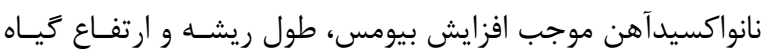
شد (Rui et al., 2016). بنابراين تحقيق در اين زمينه مى بـوانـد

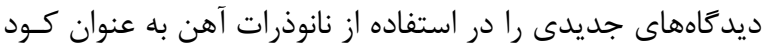
در كشاورزى بايدار ايجاد كند.

هدف از مطالعه حاضر ير نمودن خلاهاى تحقيقـاتى در زمينــا

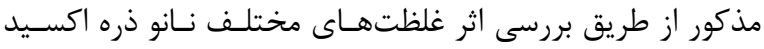

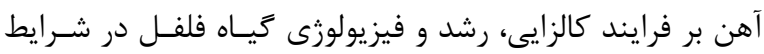

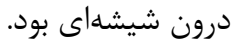

\section{مواد و روشها} تهيه استوك نانو اكسيد آهن

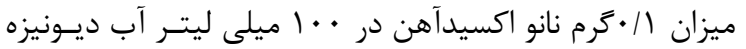

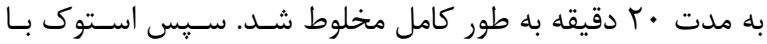

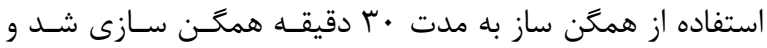

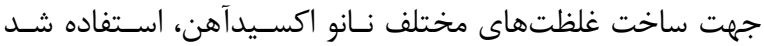

.(Dhoke et al., 2013)

\section{شرايط كشت و اعمال تيمارها}

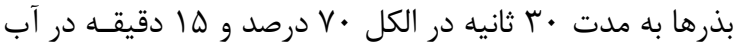
زاول ه درصد ضدعفونى و سيس به مدت ها دقديقه با آب مقطر شستشو داده شدند. از محيط كشت MS در اين مطالعه اسـتفاده شد (Murashige \& Skoog, 1962). بذرهاى ضدعفونى شـده در محيط كشت بدون هورمون حـاوى غلظـتهـاى مختلـف نـانو
مقال

فلفل با نـام علمسى Capsicum annuum L. متعلـق بـهـ تيـره

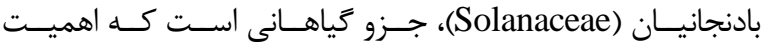

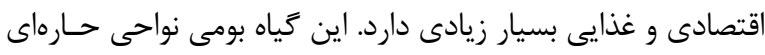

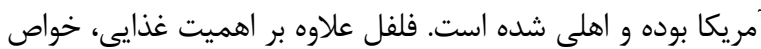
آنتى اكســيدانى نيـز دارد (Ghasemnezhad et al., 2011).

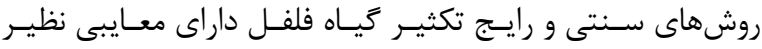

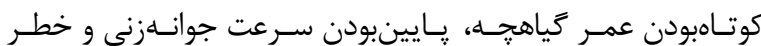

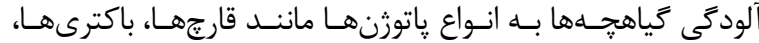

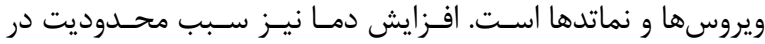

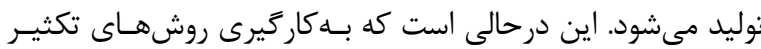
جديد و رايج از طريق بيوتكنولوزى، موجب افـزايش كمسى و ارتقــا كيفى محصول مىشود (Hussain et al.,1999).

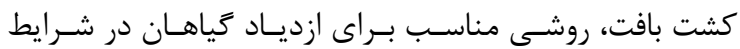

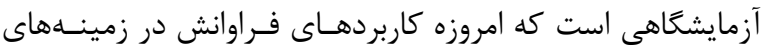

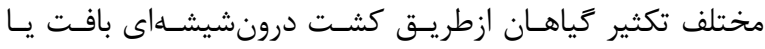

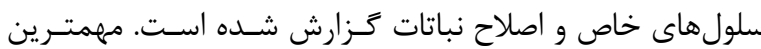
مورد قابلتوجه در كشتهاى درونشيشهاى، عارى بـودن محسيط

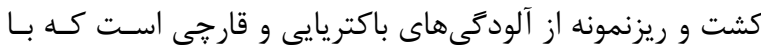

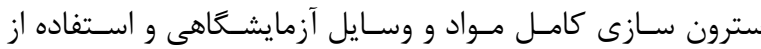

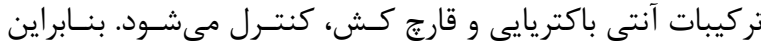

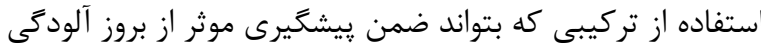

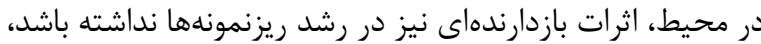

مى تواند بسيار مفيد واقع شود (Phillips \& Garda, 2019).

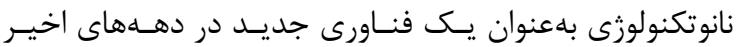

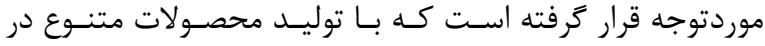
بخشهاى شيمى، انرزى و محيط زيست كاربردهاى فراوانى دارد.

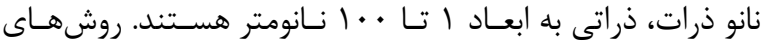
نوين و كاربردى كشت سلول و بافت در بهنزادى و ازدياد كياهـان

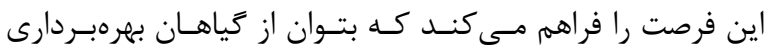
بيشترى كرد و به مقدار بيشتـرى از تركيبـات ثانويـهـ ارزشـمند

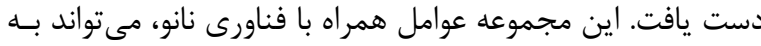

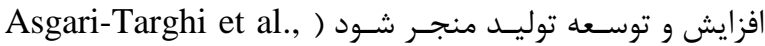
2018). كـاربرد نـانو ذرات در محسيط درون شيشـهاى مسىتوانسـ

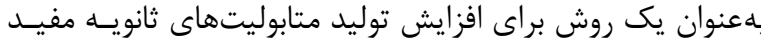

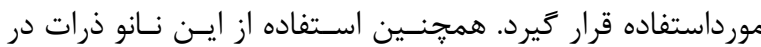

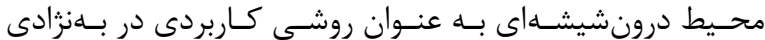

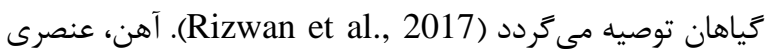
ضرورى براى فرايندهاى متابوليك كياه، سنتز DNA، فتوسنتز، و و

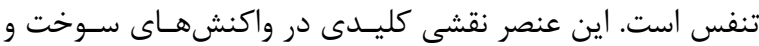


نسبت به تيمار شاهد شد اما دو گروه ديخر تيمارهاى نانواكسيد

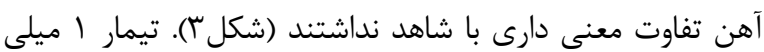

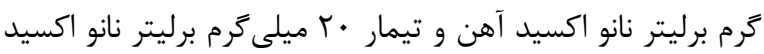
آهن بيشترين اثر را به روى افزايش كلروفيل b كياه نشان داد. غلظت · ا ميلى دارى در غلظت كلروفيل b نسبت به تيمار شاهد نشد (شكل بلى). نمونههاى تيمار شده با غلظت • † نيز به مقدار معنى دارى بالاتر از

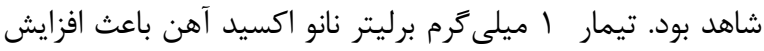

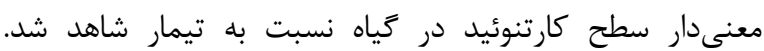

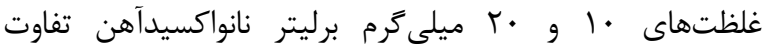

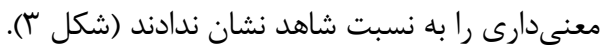
القا كالوس درغلظتهاى غلظتهاى مختلف نانواكسيد آهن، غلظـت آهن رشد كالوس را نسبت به تيمار شاهد و ساير تيمارها به نحــو

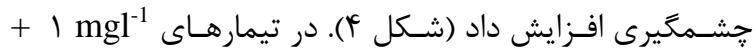

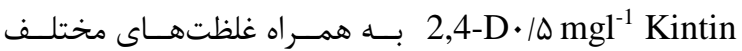
نانواكسيد آهن، تيمار

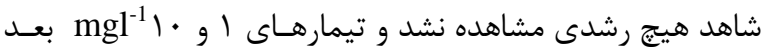
از له هفته رشد كردند (شكل ف). در تيمارهاى هورمونى

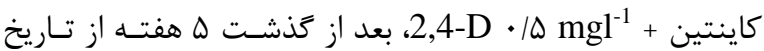

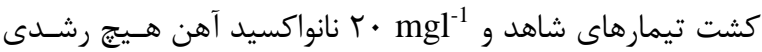
نكردند؛ امـا تيمـار

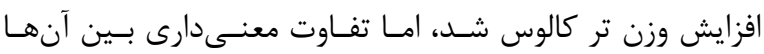

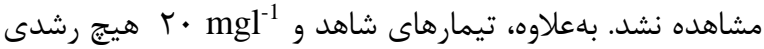
نكردند (شكل ع). دررابطه با وزن خشك كالوس، تيمـار

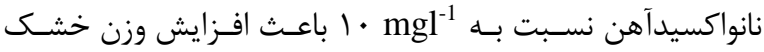
كالوس شد اما تفاوت معنى دارى بين آنها مشاهده نشـد (شـكل ؟). در مورد محيط كالوس، تيمارهـاى شـاهد و

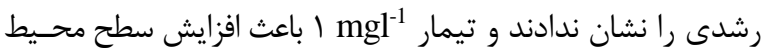
كالوس نسبت بـه تيمـار mgl

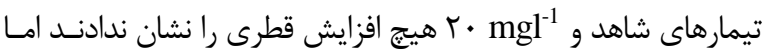

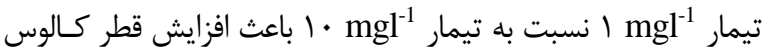

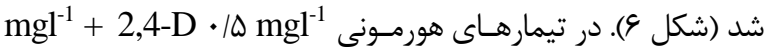

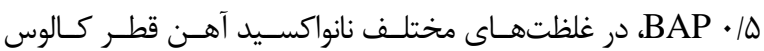
نسبت به گروه شاهد افزايش معنى دارى را نشان داد. اما تفـاوت

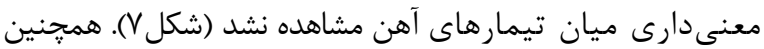

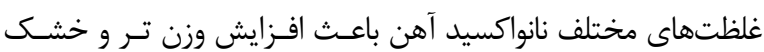
كالوس نسبت به تروه شاهد شد، اما تفاوت معنى دارى ميان تيمارهـا

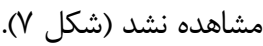

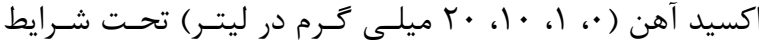

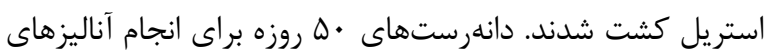
مربوط برداشت شدند. شاخصهاى مختلف ريخت شناسـى ماننـد دهد

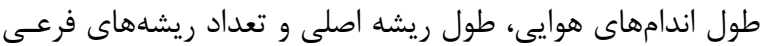

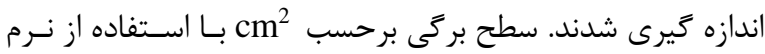

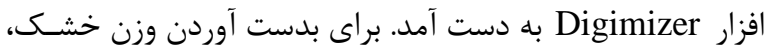

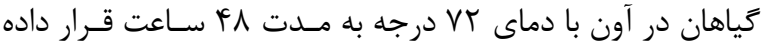
شدند و سيس وزن شدند. سنجش كلروفيل

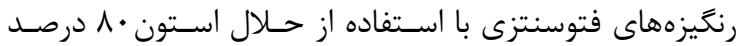

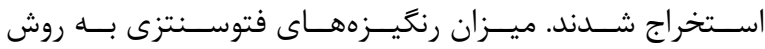
اسيكتروفتومترى تعيين شد (Arnon, 1949). جذب نمونهها در طول موجهاى هF آزمايش كالزايى مولى

به منظور بررسى اثر به كارگيرى غلظتهاى مختلف نانواكسـيد

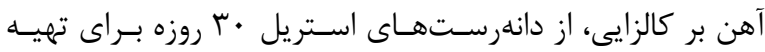
جداكشت اسـتفاده شـد. در ايـن بخـش، كـالزايى در دو شـرايط

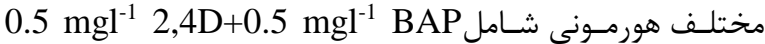

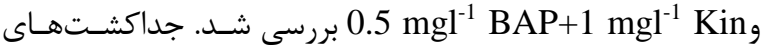

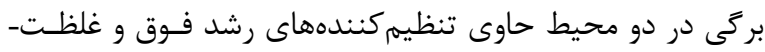

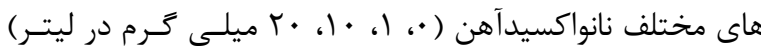

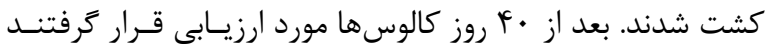
(Asgari- Targhi, et al., 2018) آناليز آمارى طرح آزمايش، كاملا تصادفى با ب تكرار بود. اطلاعات بدسـت آمـده

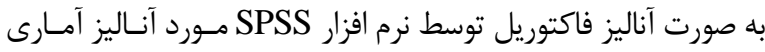
قرار گرفتند. از آزمون دانكن براى مقايسه ميانگينها استفاده شد.

\section{نتابج}

رشد و ريخت شناسى به كارگيرى غلظتهاى مختلف نانواكسيد آهن موجب تغيير در نرخ رشد و مورفولوزى گياه شد (شكل ()). بررسى اثر بهكاركيرى غلظتهاى مختلف نانو اكسيد آهن بر بيومس نشان داد كه هر سه غلظت بكاركرفته شده موجب افزايش معنى دار (\$) \$ p) وزن تر ريشه، وزن

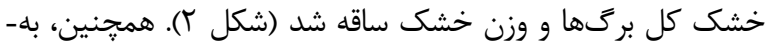
كارگيرى غلظتهاى مختلف نانو اكسيد آهن موجب افزايش معنى دار (p \$).05) طول ساقه، ارتفاع كل گياه و طول ريشه شد (شكل r). رنغَيزههاى فتوسنتزى نتايج نشان داد كه تيمار ا ميلى معنى دار كلروفيل a در بين غلظتهاى مختلف نانو اكسيد آهن 


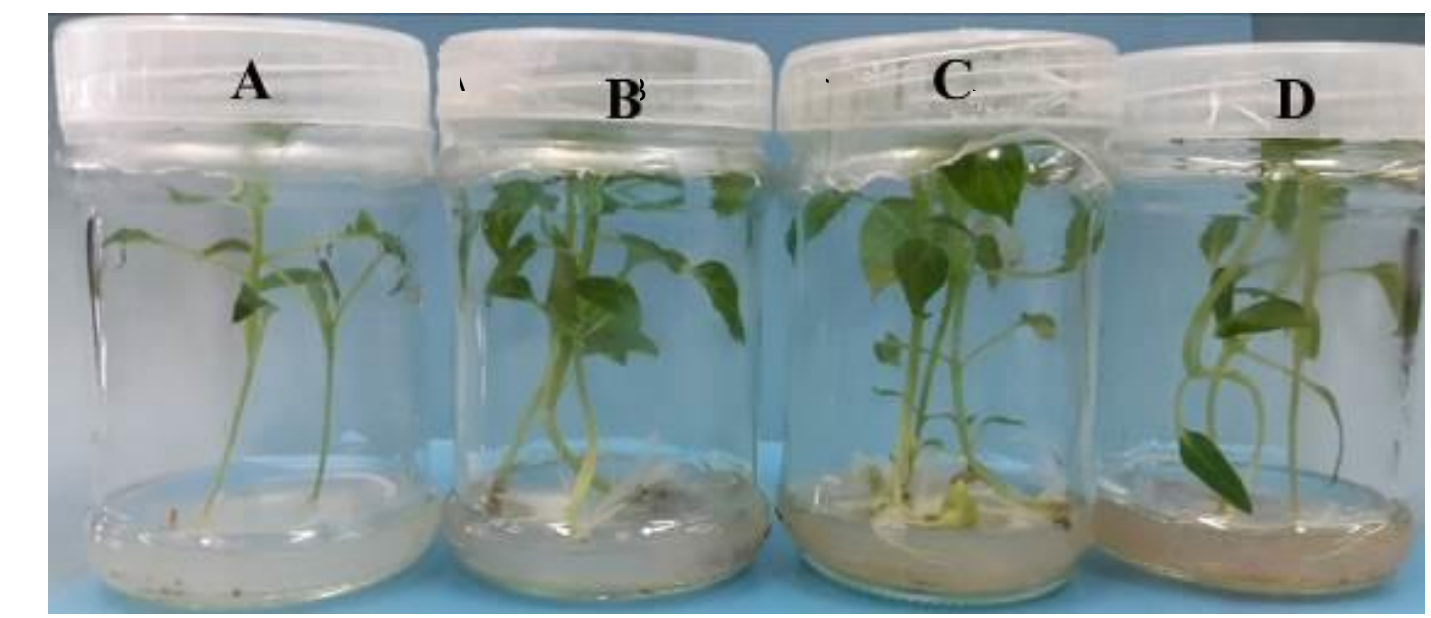

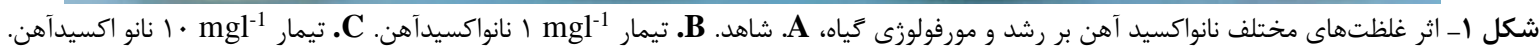

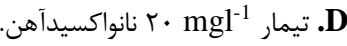

Fig. 1. The effect of the different concentrations of FeO NP on plant morpholgy and growth; A. Control. B. FeO NPs of $1 \mathrm{mgl}^{-1}$. C. FeO NPs of $10 \mathrm{mgl}^{-1}$. D. FeO NPs of $20 \mathrm{mgl}^{-1}$.

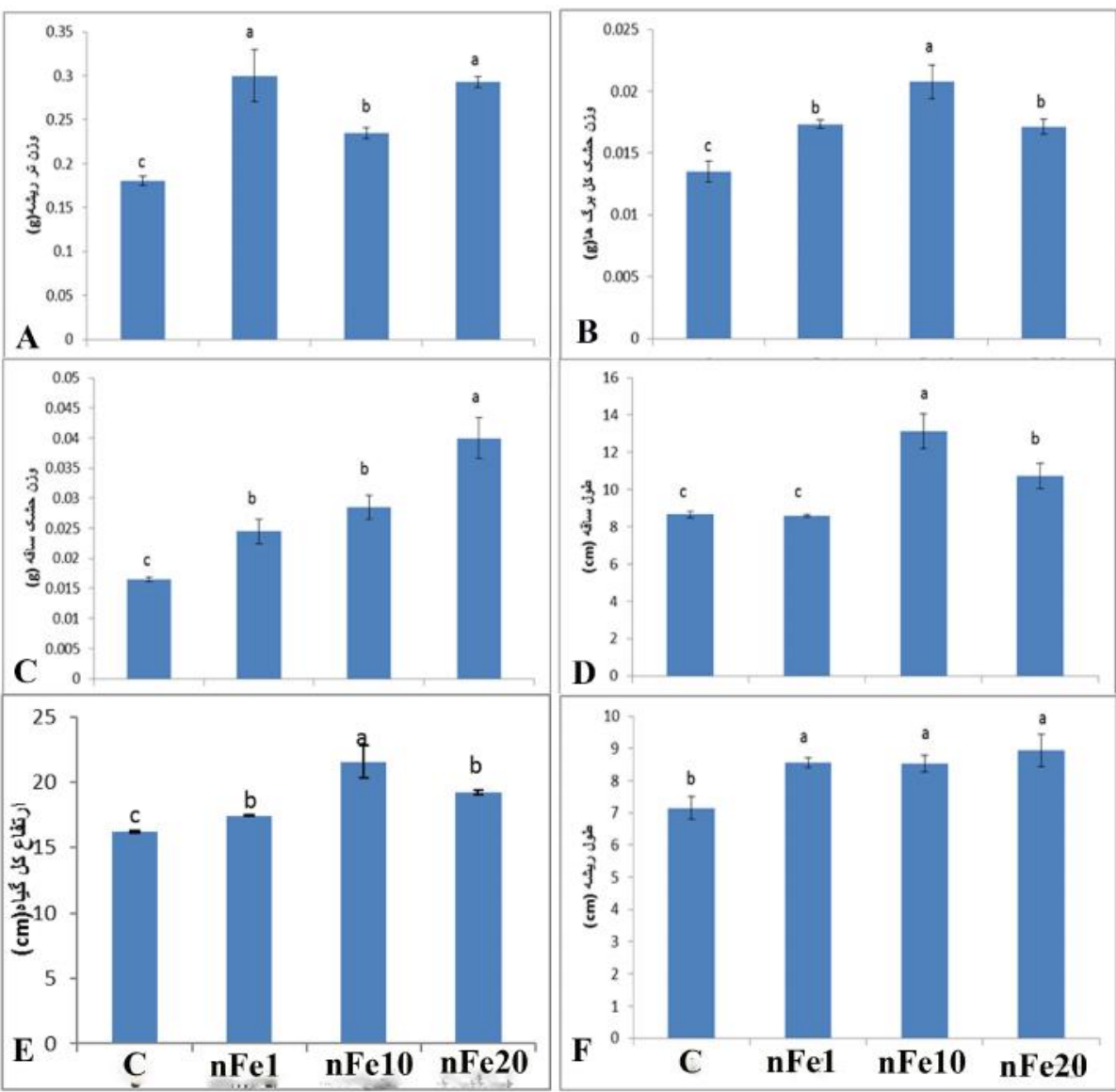

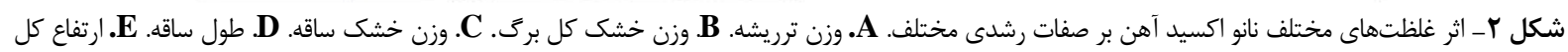

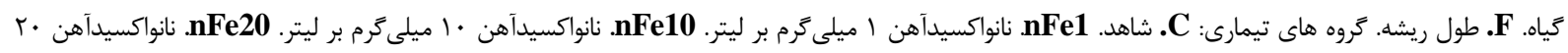
ميلى

Fig. 2. The effects of the different doses of FeO NPs on the various growth-related traits. A. root fresh mass. B. dry mass of total leaves. C. stem dry mass. D. stem length. E. plant total height. F. root length. Treatment groups: C. Control. nFe1. FeO NPs of $1 \mathrm{mgl}^{-1}$. nFe10. FeO NPs of $10 \mathrm{mgl}^{-1}$. nFe20. FeO NPs of $20 \mathrm{mgl}^{-1}$. 


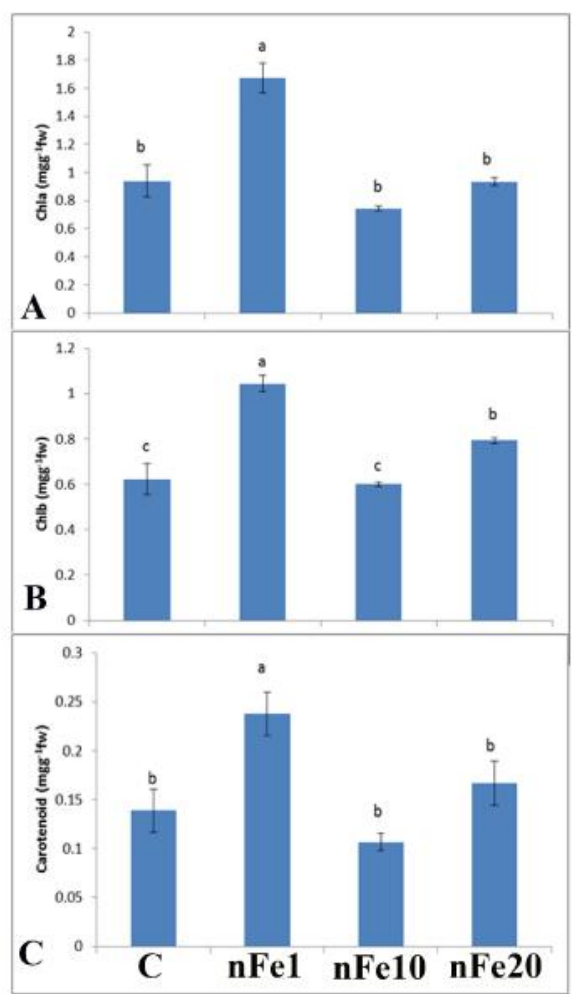

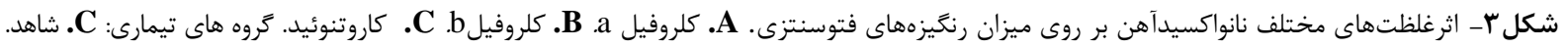

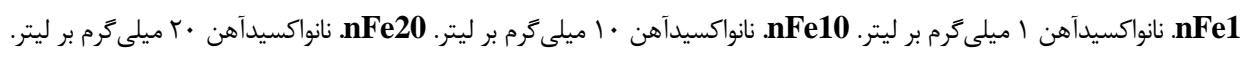

Fig. 3. The effects of the different doses of FeO NPs on photosynthetic pigments. A. Chla. B. Chlb. C. carotenoids. Treatment groups: C. Control. nFe1. FeO NPs of $1 \mathrm{mgl}^{-1}$. nFe10. FeO NPs of $10 \mathrm{mgl}^{-1}$. nFe20. FeO NPs of $20 \mathrm{mgl}^{-1}$.

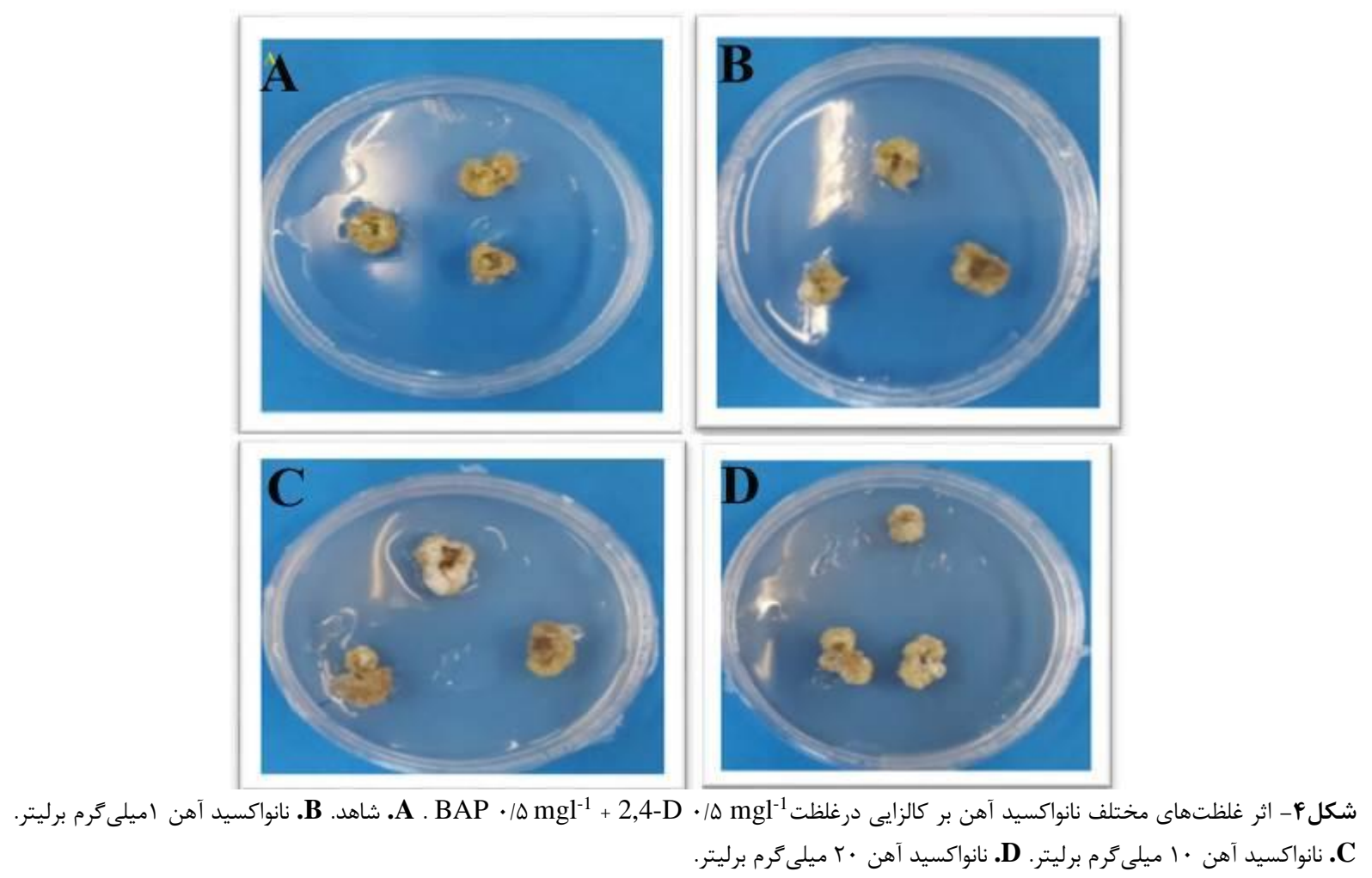


Fig. 4. The effect of the different concentrations of FeO NPs on callogenesis under $0.5 \mathrm{mgl}^{-1} \mathrm{BAP}+0.5 \mathrm{mgl}^{-1} 2,4 \mathrm{D}$. A. Control. B. FeO NP of $1 \mathrm{mgl}^{-1}$. C. FeO NP of $10 \mathrm{mgl}^{-1}$. D. FeO NP of $20 \mathrm{mgl}^{-1}$.
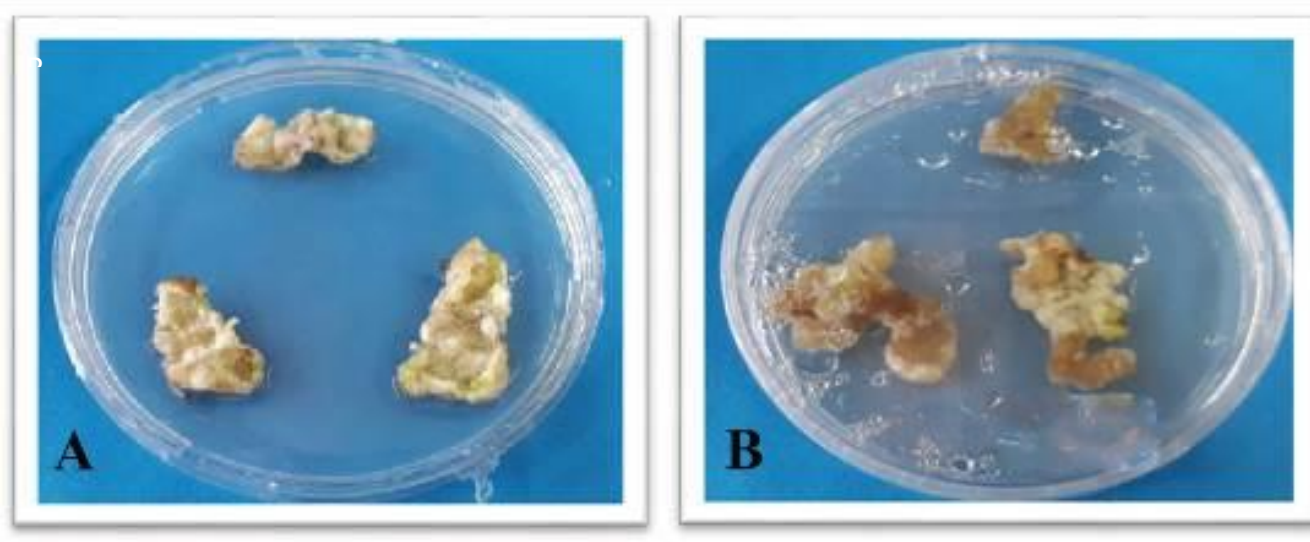

شكل ه- اثر غلظتهاى مختلف نانواكسيد آهن بر كالزايى تحت آهن • • ميلى

Fig. 5. The effects of the different concentrations of FeO NPs on callogenesis under $0.5 \mathrm{mgl}^{-1} \mathrm{BAP}+1 \mathrm{mgl}^{-1} \mathrm{Kin}^{-\mathbf{A}}$. $\mathrm{FeO} \mathrm{NP}$ of $1 \mathrm{mgl}^{-1}$. B. FeO NP of $10 \mathrm{mgl}^{-1}$.
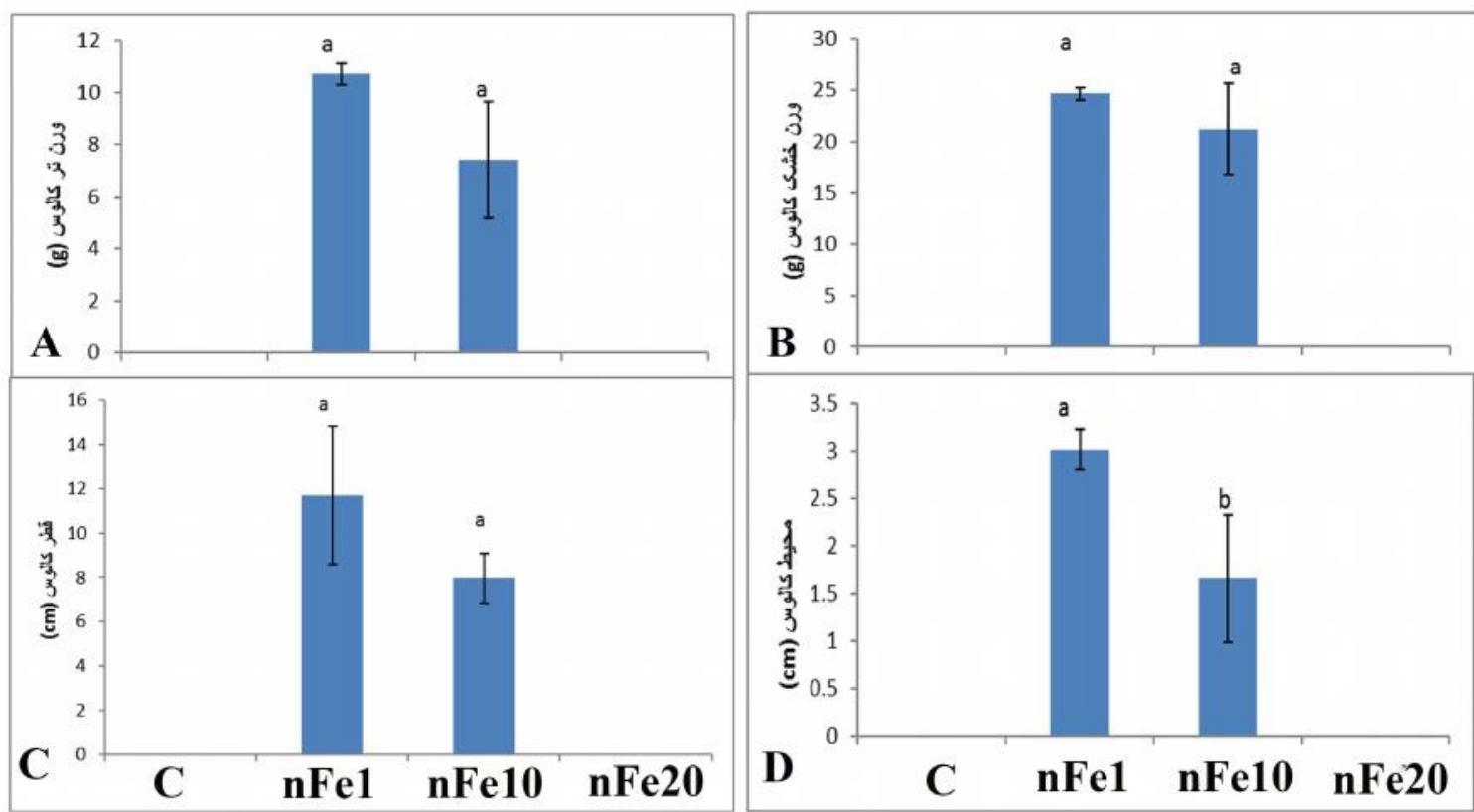

شكل \&- اثر غلظتهاى مختلف نانواكسيدآهن بر صفات مختلف تحت تيمارهاى هورمونى

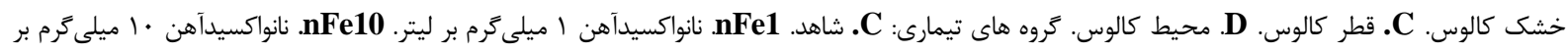

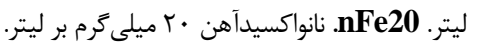

Fig. 6. The effects of different concentrations of FeO NPs on various traits under $0.5 \mathrm{mgl}^{-1} \mathrm{BAP}+1 \mathrm{mgl}^{-1} \mathrm{Kin}^{-\mathrm{A}}$. callus fresh mass. B. Callus dry mass. C. callus diameter. D. callus area. Treatment groups: C. Control. nFe1. FeO NPs of 1 $\mathrm{mgl}^{-1}$. nFe10. FeO NPs of $10 \mathrm{mgl}^{-1}$. nFe20. FeO NPs of $20 \mathrm{mgl}^{-1}$. 


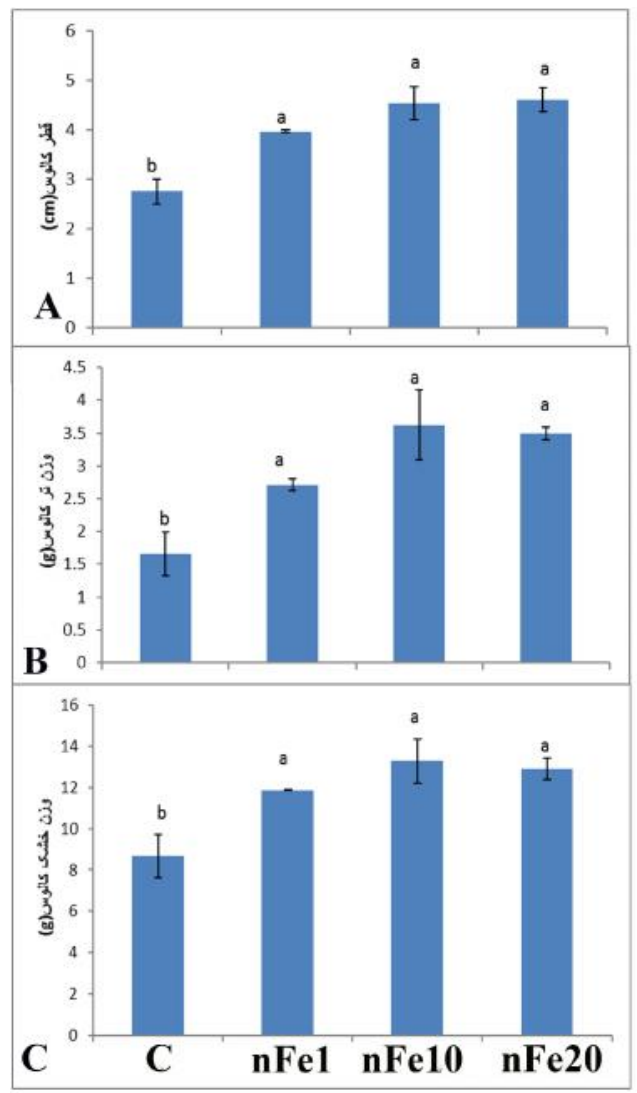

شكل V- اثر غلظتهاى مختلف نانواكسيدآهن بر صفات مختلف تحت تيمارهاى هورمونى

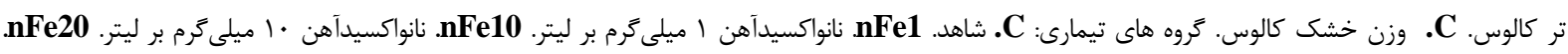

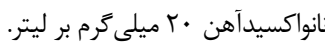

Fig. 7. The effects of the different concentrations of FeO NPs on various traits under $0.5 \mathrm{mgl}^{-1} 2,4 \mathrm{D}+0.5 \mathrm{mgl}^{-1} \mathrm{BAP}$. A. callus diameter. B. fresh mass. C. callus dry mass. Treatment groups: C. Control. nFe1. FeO NPs of $1 \mathrm{mgl}^{-1}$. nFe10. FeO NPs of $10 \mathrm{mgl}^{-1}$. nFe20. FeO NPs of $20 \mathrm{mgl}^{-1}$.

نتايج اين تحقيق، به كارگيرى نـانو اكسـيد آهـن باعـث افـزايش

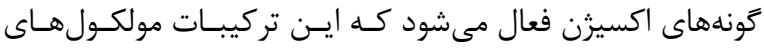

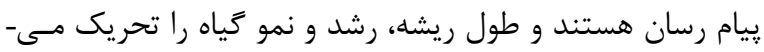

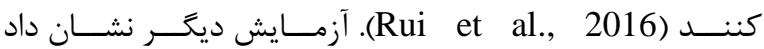
نانواكسيدآهن بر رشد گياه آرابيدويسيس تالينا در كشت گلــدانى تـاثير بازدارنـدگى دارد كـهـ بـا نتـايج ايـن تحقيـق مغـايرت دارد

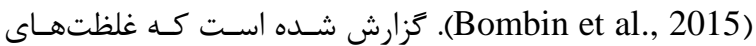
a مختلف نانواكسيد آهن موجب افزايش معنى دار غلظت كلروفيل

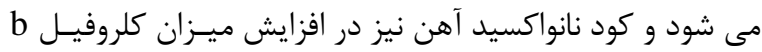
موثرتر از كلات آهن عمل مىنمايسد (Peyvandi et al., 2011).

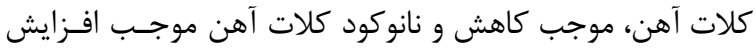
ميزان كلروفيلهاى a و b ميىشـود (Peyvandi et al., 2011).

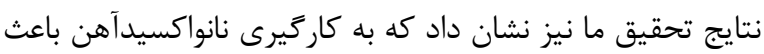
افزايش غلظـت رنخيزههـاى فتوســتزى (كلروفيلهـاى a و b) و و

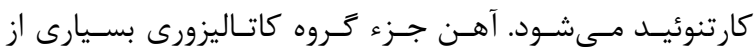

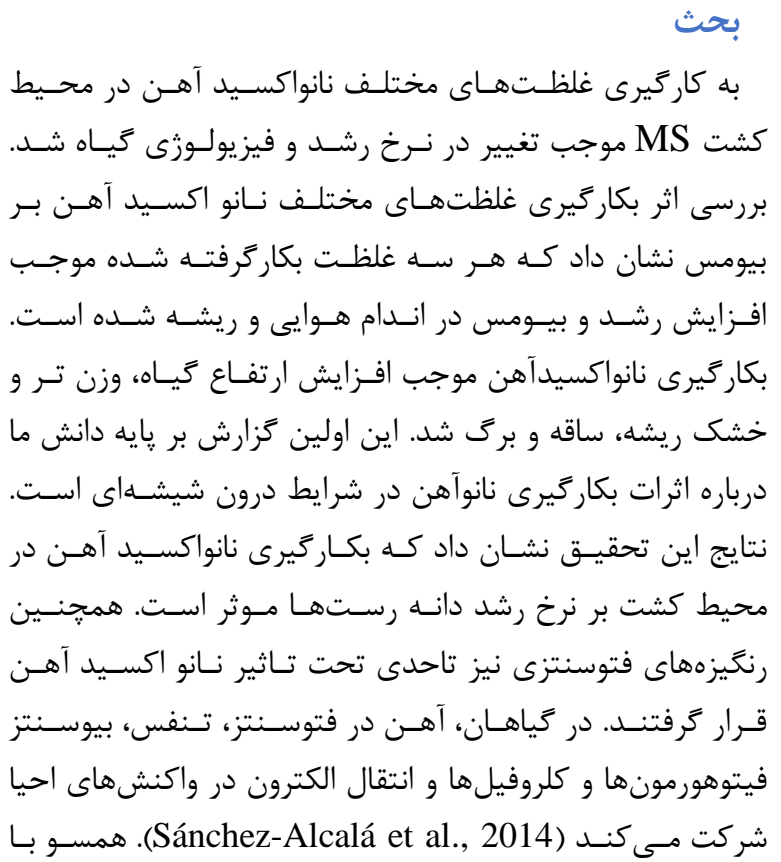




\section{REFERENCES}

Arnon, D.I. 1949. Copper enzymes in isolated chloroplasts Polyphenoloxidase in Beta vulgaris. Plant Physiol. 24: 1-15.

Asgari-Targhi, G., Iranbakhsh, A. \& Ardebili, Z.O. 2018. Potential benefits and phytotoxicity of bulk and nano-chitosan on the growth, morphogenesis, physiology, and micropropagation of Capsicum annuum. Plant Physiol. Biochem. 127: 393-402.

Barberon, M., Zelazny, E., Robert, S., Conéjéro, G., Curie, C., Friml, J. \& Vert, G. 2011. Monoubiquitindependent endocytosis of the iron-regulated transporter 1 (IRT1) transporter controls iron uptake in plants. Proc. Natl. Acad. Sci. 108: 450-E458.

Balakrishnan, K., 2000. Peroxidase activity as an indicator of the iron deficiency in banana. Indian J. Plant Physiol. 5: 389-391.

Bombin, S., LeFebvre, M., Sherwood, J., Xu, Y., Bao, Y. \& Ramonell, K. 2015. Developmental and reproductive effects of iron oxide nanoparticles in Arabidopsis thaliana. Int. J. Mol. Sci. 16: 24174-24193.

Dhoke, S.K., Mahajan, P., Kamble, R. \& Khanna, A. 2013. Effect of nanoparticles suspension on the growth of mung (Vigna radiata) seedlings by foliar spray method. Nanotechnol. Dev. 3:1-23.

Ghasemnezhad, M., Sherafati, M. \& Payvast, GA. 2011. Variation in phenolic compounds, ascorbic acid and antioxidant activity of five coloured bell pepper (Capsicum annum) fruits at two different harvest times. J. Func. Food 1: 44-9.

Hussain, S., Jain, A. \& Kothari, S.L. 1999. Phenylacetic acid improves bud elongation and in vitro plant regeneration efficiency in Capsicum annuum L. Plant Cell Rep. 19: 64-68.

Jeyasubramanian, K., Thoppey, U.U.G., Hikku, G.S., Selvakumar, N., Subramania, A. \& Krishnamoorthy, K. 2016. Enhancement in growth rate and productivity of spinach grown in hydroponics with iron oxide nanoparticles. Rsc. Adv. 6: 15451-15459.

Lombardi, L., Sebastiani, L. \& Vitagliano, C. 2003. Physiological, biochemical, and molecular effects of in vitro induced iron deficiency in peach rootstock Mr. S 2/5. J. Plant Nutr. 26: 2149-2163.

Murashige, T. \& Skoog, F. 1962. A revised medium for rapid growth and bio assays with tobacco tissue cultures. Physiol. Plant 15: 473-497.

Peyvandi, M., Parande, H. \& Mirza, M. 2011. Comparison of nano Chelate $\mathrm{Fe}$ with Chelate Fe; effect on growth parameters and antioxidant enzymes activity of Basilicum Ocimum. New Cell Mol. Biotech. 1: 89-99.

Rizwan, M., Ali, S., Qayyum, M.F., Ok, Y.S., Adrees, M., Ibrahim, M., Zia-ur-Rehman, M., Farid, M. \& Abbas, F. 2017. Effect of metal and metal oxide nanoparticles on growth and physiology of globally important food crops: a critical review. J. Hazard. Mat. 322: 2-16.

Rui, M., Ma, C., Hao, Y., Guo, J., Rui, Y., Tang, X., Zhao, Q., Fan, X., Zhang, Z., Hou, T. \& Zhu, S. 2016. Iron oxide nanoparticles as a potential iron fertilizer for peanut (Arachis hypogaea). Front. Plant Sci. 7: 815.
آنزيمهاى اكسيداسـيون و احيـا اسـت و بـراى ســتنز كلروفيـل

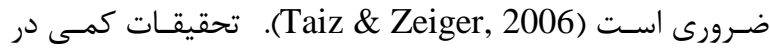

زمينــه بكـار گيرى نـانوذرات در محــيط كشـت در شــايط درون

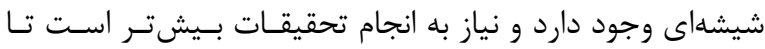
مكانيسمهاى مربوط شناسايى شود.

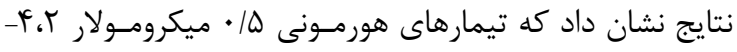

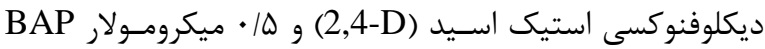
به همراه غلظتهاى مختلف نانواكسيدآهن اثر مثبتى بر زندهمانى

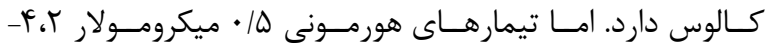
ديكلوفنوكسى استيك اسيد و |/ • ميكرومولار كينتين به همـراه غلظتهاى مختلف نانواكسيدآهن اثرى مثبت بر زندهمانى كالوس

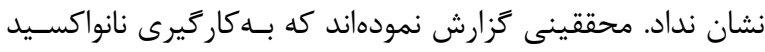
آهن در غلظتهـاى مختلـف داراى اثـر مثبـت روى زنس زنـدهمانى و

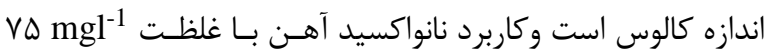

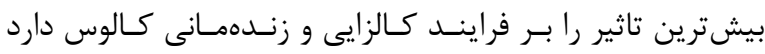

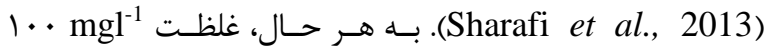
نانواكسيد آهن داراى كمترين تاثير بر فرايند كالزايى و زندهمـانى كالوس در گل راعى بود. اما نتايج اين تحقيق نشان داد كه تيمـار

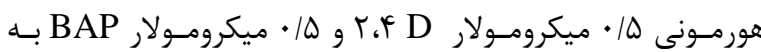

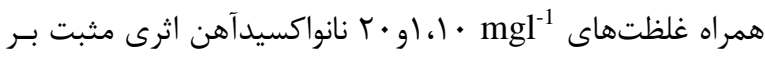

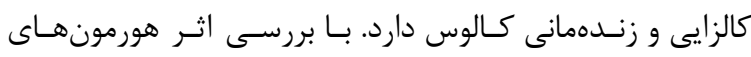

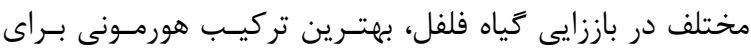
باززائى غيرمستقيم مشخص شد، بنابراين بـا بهينهســازى توليـد

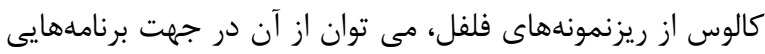

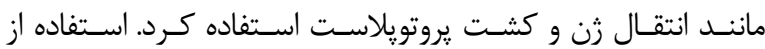
تكنيكهاى مختلف كشت بافت جهت تكثير فلفـل مى توانـد كَامى

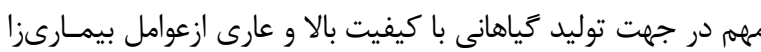

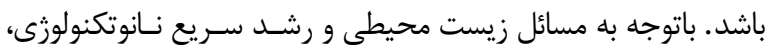

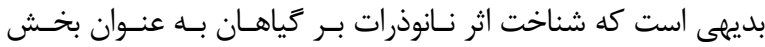

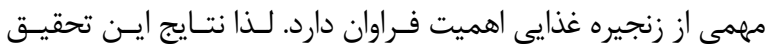
مى تواند براى ارتقا دانش در زمينه نانوتكنولوزى اثربخش بـ باشد. سباسگزן ارى اين تحقيق تحت حمايت دانشـحاه آزاد اسـلامى واحسـد علـوم و تحقيقات تهران انجام شده است. مـولفين از كارشناسـان محتـرم مجتمع آزمايشگاهى رازى سياسگزارند. 
Phillips, G.C. \& Garda, M. 2019. Plant tissue culture media and practices : an overview. In Vitro Cell. Dev. Biol. Plant 55: 242-257.

Sánchez-Alcalá, I., del Campillo, M. D., Barrón, V. \& Torrent, J. 2014. Evaluation of preflooding effects on iron extractability and phytoavailability in highly calcareous soil in containers. Plant Nutr. Soil Sci. 177: $150-158$.
Sharafi, A., Hasanloo, T., Khayam, S., Fotokian, M. \& Davoodi, D. 2013. Effects of applications of zinc oxide and iron. Oxide nanoparticles on callogenesis in Hypericum perforatum. Agric. Nat. Resources Engin. Sys. 43: 26-30.

Taiz, L. \& Zeiger, E. 2006. Plant Physiology. Sinauer Associates, Los Angeles, pp: 68-87.

How to cite this article:

Iranbakhsh, A. \& Gaderi, S.A. 2020. The effect of nano-iron oxide on growth, physiology, and callogenesis in pepper in vitro. Nova Biologica Reperta 7: 220-227. (In Persian)

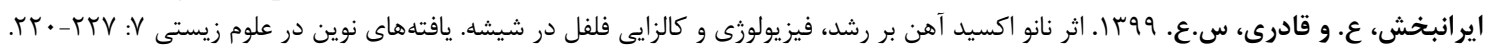

